ISSN 0258-7122

Bangladesh J. Agril. Res. 33(3) : 617-622, December 2008

\title{
EFFICACY OF RHIZOBIUM STRAINS AND BIOFERTILIZERS FOR CONTROLLING FOOT AND ROOT ROT AND INCREASING GREEN POD YIELD OF BUSH BEAN
}

\author{
K. M. KHALEQUZZAMAN ${ }^{1}$ AND I. HOSSAIN ${ }^{2}$
}

\begin{abstract}
The experiment was conducted during 2002 - 03 in the infested plot of the BINA sub-station at Ishurdi, Pabna to evaluate the effectiveness of Rhizobium strains and biofertilizers in controlling the foot and root rot disease, and to increase green pod yield of Bush bean under field condition. The highest germination (91.6\%) was recorded with BINAR P36, which was statistically similar to BAUR 107, BARIR 7029, BARIR 1000, BINAR P6 and BINA biofertilizer. The lowest germination (77.9\%) was found in untreated control. The highest foot and root rot (24.5\%) was observed in untreated control and the lowest $(10.00 \%)$ was in BINAR P36. Biofertilizers and Rhizobial strains decreased foot and root rot upto 59.2\% over untreated control. The highest green pod yield (20.8 tha) was obtained for using BINAR P36, which was followed by BARIR 7029, BARIR 892, BARIR 1000, BINAR P6 and BINA biofertilizer. The lowest green pod yield (13.6 tha) was found in untreated control. Rhizobium strain BINAR P36 may be used as seed treatment for controlling foot and root rot and increasing green pod yield of Bush bean.
\end{abstract}

Key Words: Rhyzobium, biofertilizers, foot and root rot, bush bean.

\section{Introduction}

Bush bean (Phaseolus vulgaris L.) is considered as one of the important exporting vegetables of Bangladesh. The crops is intensively cultivated popularly in Chittagong, Sylhet, North Bengal, Chittagong Hill tracts and also many other places in Bangladesh. The average green pod yield of this crop in this country is 13-14 tha (Anonymous, 2000). There are several biotic and abiotic factors behind this low yield. Foot and root rot caused by Fusarium oxysporum, Fusarium solani Scierotium rolfsii, Scierotinia scierotiorum and Rhizoctonia solani is a common disease problem in Bush bean (Abo Ellil et al., 1998; Rashid and Singh, 2000; Mozumder, 2004). The foot and root rot disease resulted in 0 $90 \%$ plant mortality of Bush bean (Chunje and Zhibiao, 1996). Chemical control of this disease obviously is costly as well as harmful for environment. On the other hand, biological control can be an effective and environmentally friendly means of combating this problem. The use of antagonistic bacteria (Rhizobia) as a biological control may provide a great scope to control the seed and soil borne

${ }^{1}$ Senior Scientific Officer, Plant Pathology Division, Regional Agricultural Research Station, BARI, Ishurdi, Pabna and ${ }^{2}$ Professor, Department of Plant Pathology, BAU, Mymensingh, Bangladesh. 
pathogens. In addition, Rhizobium would enrich soil nitrogen level through BNF (Biological Nitrogen Fixation) and the crop plants would be immensely benefited. No work was done before in Bangladesh on the foot and root rot of Bush bean by biological means. The present research was undertaken to examine the effect of Rhizobium strains and biofertilizers for controlling foot and root rot disease and to increase green pod yield of Bush bean.

\section{Materials and Method}

The experiment was carried out during 2002-2003 in the foot and root rot infested plot of the BINA sub-station. The experiment was conducted following RCBD with three replications. The size of individual unit plot was $2 \mathrm{~m} \times 2 \mathrm{~m}$. The test variety was BARI Bush bean 1. Twelve Rhizobial strains (BAUR 975, BAUR 424, BAUR 349, BAUR 107, BAUR 979, BARIR 7029, BARIR 892, BARIR 301, BARIR 1000, BARIR 609, BINAR P6 and BINAR P36) and three biofertilizers (BAU biofertilizer, BARI biofertilizer and BINA biofertilizer) were used for treating seeds. The crop spacing was $30 \mathrm{~cm} \times 15 \mathrm{~cm}$. The seeds were dipped in Rhizobial broth for 15 minutes (Somasegaran and Hoben, 1994). In the case of biofertilizers, seeds were initially moistened with molasses at the rate of $50 \mathrm{~g}$ per $\mathrm{kg}$ seed. Then the seeds were thoroughly mixed with biofertilizer (50 $\mathrm{g} / \mathrm{kg}$ seed), where each biofertilzer contained 10 Rhizobial cells/mg (Somasegaran and Hoben, 1994). In the case of control, seeds were not treated with Rhizobium strains or biofertilizers. The inoculant-coated seeds were sown in the afternoon. The plots were inspected regularly to record foot and root rot disease development from the seedling stage until maturity. The diseased plants were collected and examined for identification of pathogens. Intercultural operations were done as and when necessary. Two irrigations were done. No chemicals (insecticides or fungicides) were used for controlling pests and diseases. Data were recorded on germination (\%), foot and root rot (\%), seedling vigour, number of nodules/plant, plant height, green pods/plant and green pod yield. Vigour index (VI) or seedling vigour was calculated for 15 days' old seedlings (Baki and Anderson, 1973): Vigour index (VI) $=($ Mean shoot length + mean root length) x Germination (\%) Data were subjected to statistical analysis for mean values and test of significance. The variations among the means were compared following Duncan's Multiple Range Test (DMRT) (Gomez and Gomez, 1984).

\section{Results and Discussion}

Results of seed treatment with Rhizobium strains and biofertilizers on germination and foot and root rot of the crop (BARI Bush bean 1) are shown in Table 1 . Both the parameters were significantly influenced by Rhizobium strains and biofertilizers. The highest germination (91.6\%) was recorded when seeds 
were treated with BINAR P36, which was statistically similar to BAUR 107(85.7\%), BARIR 7029(87.8\%), BARIR 1000 (88.1\%), BINAR P6(89.8\%) and BINA biofertilizer (90.5\%), the lowest germination (77.9\%) being observed in untreated control. The highest foot and root rot (24.5\%) was found in untreated control and the lowest $(10.0 \%)$ was in BINAR P36, which was statistically similar to BARI 7029 (12.8\%), BARI 892 (13.2\%), BARI 1000 (12.0\%), BINAR P6 (12.5\%) and BINA biofertilizer (11.1\%). Biofertilizers and Rhizobial strains decreased foot and root rot upto 59.2\% over untreated control.

Table 1. Effect of seed treatment with Rhizobium strains and biofertilzers on germination and foot and root rot of cv. BARI Bush bean

\begin{tabular}{|c|c|c|c|}
\hline $\begin{array}{l}\text { Rhizobium strains and } \\
\text { biofertilizers }\end{array}$ & $\begin{array}{l}\text { Germination of } \\
\text { seeds (\%) }\end{array}$ & $\begin{array}{l}\text { Foot and root rot } \\
\qquad(\%)\end{array}$ & $\begin{array}{l}\text { Foot and root } \\
\text { rot reduction } \\
\text { over control } \\
\text { (\%) }\end{array}$ \\
\hline BAUR 975 & 83.7 b-f & $13.8 \mathrm{~d}-\mathrm{g}$ & 43.6 \\
\hline BAUR424 & 79.9ef & 17.Obcd & 30.6 \\
\hline BAUR 349 & 79.3 ef & 17.6 be & 28.2 \\
\hline BAUR 107 & 85.7 a-e & 15.9 cde & 35.3 \\
\hline BAUR 979 & 80.6 def & $15.2 \mathrm{c}-\mathrm{g}$ & 38.1 \\
\hline BAU biofertilizer & 78.9 ef & 17.3 bed & 29.5 \\
\hline BARIR 7029 & $87.8 \mathrm{a}-\mathrm{d}$ & $12.8 \mathrm{e}-\mathrm{h}$ & 47.8 \\
\hline BARIR892 & $82.7 c-f$ & $13.2 \mathrm{e}-\mathrm{h}$ & 46.3 \\
\hline BARIR3O1 & 80.5def & $19.9 b$ & 18.8 \\
\hline BARIR 1000 & $88.1 \mathrm{abc}$ & 12.Ofgh & 51.0 \\
\hline BARIR 609 & 84.4 b-f & 15.4 c-f & 37.3 \\
\hline BARI biofertilizer & 84.0 b-f & $14.1 \mathrm{c}-\mathrm{f}$ & 38.9 \\
\hline BINAR P6 & 89.8 abc & $12.5 \mathrm{e}-\mathrm{h}$ & 49.0 \\
\hline BINARP36 & $91.6 a$ & 10.Oh & 59.2 \\
\hline BiNAbiofertilizer & $90.5 \mathrm{ab}$ & $11.1 \mathrm{gh}$ & 54.6 \\
\hline Control (untreated) & $77.9 \mathrm{f}$ & $24.5 \mathrm{a}$ & - \\
\hline
\end{tabular}

In a column, similar letters do not differ significantly at $5 \%$ level of significance

The effect of Rhizobium strains and biofertilizers on the plant growth, yield and yield attributes are presented in Table 2. The highest vigour index of seedling (2688) was obtained from BINAR P36 and the lowest (1337) was in untreated control. The highest number of nodules/plant (20.0) was observed in BINAR P36 and the lowest number (3.8) was obtained in untreated control. The tallest plant $(41.1 \mathrm{~cm})$ was observed in BINAR P36 and the shortest plant $(33.08 \mathrm{~cm})$ was in untreated control. The highest number of pods/plant (14.6) was recorded in the 
case of using BINAR P36 and the lowest (7.8) in untreated control. The highest weight of green pods/plant (72.3 g) was obtained from BINAR P36, which was statistically similar to BINA biofertilizer (68.6 g) and the lowest weight of green pods/plant $(49.1 \mathrm{~g}$ ) was recorded in untreated control. The highest green pod yield (20.8 tha) was obtained from

Table 2. Effect of seed treatment with Rhizobium strains and biofertlizers on plant growth, green pod yield and yield attributes of Bush bean I

\begin{tabular}{l|c|c|c|c|c|c}
\hline $\begin{array}{c}\text { Rhizobium strains } \\
\text { and biofertilizers }\end{array}$ & $\begin{array}{c}\text { Seedling } \\
\text { vigour }\end{array}$ & $\begin{array}{c}\text { Nn. of } \\
\text { nodules/ } \\
\text { plant }\end{array}$ & $\begin{array}{c}\text { Plant } \\
\text { height } \\
\text { at maturity } \\
\text { (cm) }\end{array}$ & $\begin{array}{c}\text { No. of } \\
\text { green } \\
\text { pods/ } \\
\text { plant }\end{array}$ & $\begin{array}{c}\text { Wt of } \\
\text { green } \\
\text { pods/ } \\
\text { plant } \\
\text { (g) }\end{array}$ & $\begin{array}{c}\text { Green pod } \\
\text { yield (t!ha) }\end{array}$ \\
\hline BAUR 975 & $1745 \mathrm{hi}$ & $5.0 \mathrm{~h}$ & $34.25 \mathrm{ef}$ & $8.94 \mathrm{de}$ & $58.93 \mathrm{def}$ & $16.25 \mathrm{bcd}$ \\
BAUR 424 & $1565 \mathrm{ki}$ & $4.2 \mathrm{hi}$ & $34.17 \mathrm{ef}$ & $8.57 \mathrm{de}$ & $53.49 \mathrm{fgh}$ & $14.75 \mathrm{bcd}$ \\
BAUR 349 & $1521 \mathrm{1}$ & $4.0 \mathrm{hi}$ & $34.00 \mathrm{ef}$ & $8.24 \mathrm{e}$ & $52.59 \mathrm{gh}$ & $14.50 \mathrm{bcd}$ \\
BAUR 107 & $1782 \mathrm{~h}$ & $4.5 \mathrm{hi}$ & $34.50 \mathrm{def}$ & $8.54 \mathrm{de}$ & $54.22 \mathrm{fgh}$ & $14.95 \mathrm{bcd}$ \\
BAUR 979 & $1721 \mathrm{i}$ & $4.7 \mathrm{hi}$ & $34.75 \mathrm{def}$ & $9.03 \mathrm{de}$ & $54.39 \mathrm{fgh}$ & $15.00 \mathrm{bcd}$ \\
BAU biofertjlizer & $1653 \mathrm{j}$ & $4.6 \mathrm{hi}$ & $34.61 \mathrm{def}$ & $8.73 \mathrm{de}$ & $52.40 \mathrm{gh}$ & $14.45 \mathrm{bcd}$ \\
BARIR 7029 & $2084 . \mathrm{e}$ & $14.0 \mathrm{e}$ & $36.43 \mathrm{ed}$ & $11.04 \mathrm{bed}$ & $62.56 \mathrm{~cd}$ & $17.25 \mathrm{a}-\mathrm{d}$ \\
BARIR 892 & $1882 \mathrm{~g}$ & $10.0 \mathrm{~g}$ & $35.47 \mathrm{de}$ & $10.03 \mathrm{ede}$ & $61.1 \mathrm{lcde}$ & $16.85 \mathrm{a}-\mathrm{d}$ \\
BARIR 301 & $1583 \mathrm{k}$ & $3.7 \mathrm{i}$ & $34.47 \mathrm{def}$ & $8.46 \mathrm{de}$ & $50.77 \mathrm{gh}$ & $14.00 \mathrm{~cd}$ \\
BARIR 1000 & $2147 \mathrm{~d}$ & $15.0 \mathrm{Od}$ & $37.43 \mathrm{bc}$ & $11.88 \mathrm{bc}$ & $63.64 \mathrm{bcd}$ & $17.55 \mathrm{a}-\mathrm{d}$ \\
BARIR 609 & $1708 \mathrm{i}$ & $4.0 \mathrm{hi}$ & $34.53 \mathrm{def}$ & $8.66 \mathrm{de}$ & $54.31 \mathrm{fgh}$ & $14.99 \mathrm{bed}$ \\
BARI biofertilizer & $1964 \mathrm{f}$ & $12.0 \mathrm{f}$ & $35.47 \mathrm{de}$ & $9.73 \mathrm{ede}$ & $56.39 \mathrm{efg}$ & $15.55 \mathrm{bed}$ \\
BINARP6 & $2387 \mathrm{c}$ & $17.0 \mathrm{c}$ & $38.13 \mathrm{bc}$ & $12.24 \mathrm{abc}$ & $66.09 \mathrm{bc}$ & $17.95 \mathrm{abc}$ \\
BINAR P36 & $2687 \mathrm{a}$ & $20.0 \mathrm{a}$ & $41.13 \mathrm{a}$ & $14.58 \mathrm{a}$ & $72.25 \mathrm{a}$ & $20.75 \mathrm{a}$ \\
BINA biofertilizer & $2435 \mathrm{~b}$ & $18.0 \mathrm{~b}$ & $39.22 \mathrm{~b}$ & $12.95 \mathrm{ab}$ & $68.64 \mathrm{ab}$ & $18.65 \mathrm{ab}$ \\
Control(untreated) & $1337 \mathrm{~m}$ & $3.8 \mathrm{i}$ & $33.08 \mathrm{f}$ & $7.80 \mathrm{e}$ & $49.14 \mathrm{~h}$ & $13.55 \mathrm{~d}$ \\
\hline
\end{tabular}

In a column, similar ietters do not differ significantly at $5 \%$ level of significance

BINAR P36 followed by BARIR 7029, BARIR 892, BARIR 1000, BINAR P6 and BINA biofertilizer. The lowest green pod yield (13.55 tha) was found in untreated control.

Blum et al. (1989) reported that Rhizobium strains (573-127K14 and 5762535) decreased the incidence of damping off disease in Bush bean and the index of disease severity caused by Rhizoctonia solani, $R$. meiioti, $R$. leguminosarum and Bradyrhizobium japonicum was reduced by Fusarium spp. in soybean, mungbean, sunflower and okra plants (Haque and Ghaffar, 1993; Ghaffar, 1993). 
Hossain (2000) found that treatment of seeds with biofertilizer resulted in 85.2 and $73.1 \%$ reduction in death of plants due to infection by Fusarium oxysporum in lentil and chickpea, respectively, while Hossain et al. (2000) observed that the highest reduction (69.4\%) of Fusarial foot and root rot in chickpea over untreated control was with Rhizobium inoculation @ 50 g/kg seed (when moistened with molasses). Hossain (2000) found that treatment of seeds with biofertilizer also showed 76.7 and $87 \%$ reduction in death of plants of lentil and chickpea, respectively, due to infection by Sclerotium rolfsii. Rhizobium strain BINAR P36 gave the highest vigour index followed by BINAR P6 and BINA biofertilizer, similar results were found by using Rhizobium in their experiments (Beigh et al., 1998; Hossain et al., 1999; Kumar et al., 2001; Kibria and Hossain, 2002). The highest number of nodules/plant was observed in BINAR P36. Solaiman (1999) found that number of total nodules per plant (26.0) and dry weight of nodules per plant (153mg) of chickpea were significantly increased by Rhizobium inoculation. Hossain and Mohammed (2002) observed that biofertilizers of BARI and BINA profoundly increased the number of nodules/plant by 38.9 and $50.7 \%$ in BlNAmoog-3, respectively and by 79.0 and $165.1 \%$, respectively in BlNAmoog-4. The highest number and weight of green pods per plant were recorded by using BINAR P36, which was followed by BINAR P6 and BINA biofertilizer. The highest green pod yield was obtained by using BINA P36 which was followed by BINAR P6 and BINA biofertilizer. Pal and Ghosh (1986) reported that seed inoculation with Rhizobium leguminosarum strain L 25 and L 20 increased seed yield by $59.8 \%$ in lentil and up to $38.87 \%$ in chickpea.

It may be concluded that Rhizobium strain BINAR P36 largely controlled the foot and root rot and produced higher green pod yield of Bush bean. This strain may be used for production of biofertilizers and be used as seed treatment for controlling foot and root rot and increasing green pod yield of Bush bean.

\section{References}

Abo Ellil, A. H. A., S. T. A. El-Haleem and N. G. H. Awad. 1998. Bio-control of vegetable root rots disease. African J. Mycol. and Biotechnol. 6(1): 41 —55.

Anonymous. 2000. Shabjir Unnata Jat 0 Utpadan Padhati (Bangla). Vegetable section, Horticulture Research Centre, BARI, Joydebpur, Gazipur. pp. 27-28.

Baki, A. A. and J. D. Anderson. 1973. Vigour determination in soybean by multiple criteria. Crop Sci. 13: 630-633.

Beigh, G. M., G. H. Dar, B. A. Bhat and M. Y. Zargar. 1998. Biological control of Fusarium root rot in common bean (Phaseolus vulgaris) with Rhizobium leguminosarum. J. Hill Res. 11(2): 166-170.

Blum, L. K., S. D. Frey and G. Soto. 1989. Effect of fluorescent-pigment producing Rhizobium on the severity of Rhizoctonia solanI seed and root rot of Phaseolus 
vulgaris. A paper presented at a symposium held at the Beltsville Agricultural Research Center (BARC), held on 8-11 May, 1989.

Chunje, L. and N. Zhibiao.1996. Occurrence and damage of foot rot in spring broad bean in Linxia area. Plant Protect. 22(6): 25-26.

Ghaffar, A. 1993. Rhizobia as bio-control organisms. BNF Bulletin, 12 (2): 6.

Gomez, K. A and A. A. Gomez. 1984. Statistical procedures for Agricultural Research, lnt. Rice Res. Inst. John Willy and Sons, New York.

Haque, S. E. and A. Ghaffar. 1993. Use of Rhizobia in the control of root rot disease of sunflower, okra, soybean and mungbean. J. Phytopathol. 138 (2): 157-1 63.

Hossain, I. 2000. Biocontrol of Fusarium oxysporum and Scierotium rolfsii infection in lentil, chickpea and mungbean. BAU Res. Prog. 11: 61.

Hossain, I. and D. Mohammed. 2002. Seed treatment with biofertilizer in controlling diseases of mungbean. BAU Res. Prog. 12:34.

Hossain, I., M. A. I. Khan and A. K. Podder. 1999. Seed treatment with Rhizobium in controlling Fusarium oxysporum and Scierotium rolfsii for biomass and seed production of lentil (Lens culinaris M.). Bangladesh J. Environ. Sci. 5: 61-64.

Hossain, I., M. A. Jalil, M. A. I. Khan and F. M. Aminuzzaman. 2000. Seed treatment with Rhizobium and N P K nutrition on disease incidence and yield of chickpea (Cicer arietinum L.). Bangladesh J. Seed Sci. \& Tech. 4 (1\&2):1—6.

Kibria, M. G. and I. Hossain. 2002. Effect of biofertilizer and Rhizobium on foot and root rot disease and seed yield of mungbean. Bangladesh J. Seed Sci. \& Tech. 6 (1\&2) : 41- 45.

Kumar B. S. D., I. Berggren and A. M. Martensson. 2001. Potential for improving pea production by co-inoculation with fluorescent Pseudomonas and Rhizobium. Plant and Soil 229 (1): 25-34. 5

Mozumder, S. N. 2004. Unnata Padhatite Jharsheemer Chash (Bangla). Krishikatha, 63 (9) $269-273$.

Pal, S. C and G. Ghosh. 1986. Response to lentil and chickpea to inoculation with different strain of Rhizobium leguminosarum. Environment and Ecology 4 (4) : 630-632.

Rashid, M. A. and D. P. Singh. 2000. A Manual on Vegetable Seed Production in Bangladesh. AVRDC-USAID--Bangladesh Project, Horticulture Research Centre, Bangladesh Agricultural Research Institute, Joydebpur, Gazipur, Bangladesh. p. 73.

Solaiman, A. R. M. 1999. Influence of Rhizobium inoculant, nitrogen and boron on nodulation, dry weight and grain yield of chickpea. Annals of Bangladesh Agric. 9 (1): $75-84$.

Somasegaran, P. and H. J. Hoben. 1994. Handbook for Rhizobia : Methods in Legume Rhizobium Technology. Springer-Verlag New York, Inc., 175 Fifth Avenue, New York, NY 10010, USA. pp. 337 \& 415. 